\title{
Europäische Ursprünge der Regulierung von Wettbewerb
}

Eine rechtshistorische interdisziplinäre Suche nach einer europäischen Regulierungstradition am Beispiel der Entwicklung der Eisenbahn in England, Preußen und den USA

[The European Origins of Competition Regulation. An Interdisciplinary Search for a European Regulatory Tradition from the Perspective of the History of Law as Exemplified by the Development of the Railroads in England, Prussia and the USA]

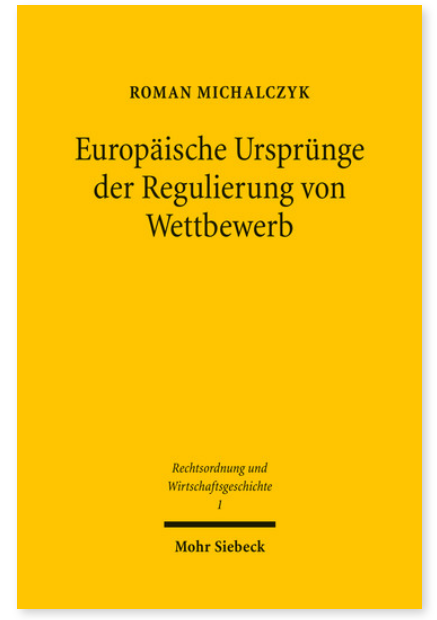

2010. XIV, 302 pages. ROWG 1

ISBN 978-3-16-150638-3 cloth $94,00 €$

ISBN 978-3-16-160606-9

eBook PDF 94,00€

\section{Published in German.}

Roman Michalczyk imparts new knowledge on the general discussion on regulation in Europe and the USA. He describes the historical situation which was the basis for the development of the regulation as well as the political, economic and legal factors which interacted to enable Europe to look back on its own, non-American regulatory tradition which already existed in the 19 th century.

Roman Michalczyk Geboren 1982; Studium der Rechtswissenschaft in Bonn und Madrid; 2010 Promotion; seit 2009 wissenschaftlicher Mitarbeiter des Verbundprojektes »Gestaltung der Freiheit« und Rechtsreferendar am Landgericht Bonn.
Order now:

https://www.mohrsiebeck.com/en/book/europaeische-urspruenge-der-regulierung-von-wettbewerb-9783161506383?

no_cache=1

order@mohrsiebeck.com

Phone: +49 (0)7071-923-17

Fax: +49 (0)7071-51104 